\title{
„Z dozwoleniem” drukowane
}

W państwie Jagiellonów, a potem I Rzeczypospolitej cenzurą ksiąg, zwalczaniem niepożądanych treści zajmowały się zarówno władze świeckie, jak i kościelne. Kościół rzymskokatolicki czuwał przede wszystkim nad zgodnością ze swoim wykładem formułowanych, głoszonych pismem prawd religijnych, podobnie jak inne wyznania i kościoły, ale także pilnował przestrzegania norm obyczajowych. Na pierwszym planie pozostawało jednak zwalczanie herezji. Pomagały w tym władze świeckie. Akty prawne i realne działania cenzorskie, prewencyjne, a zwłaszcza represyjne były dziełem władz świeckich i kościelnych. Kościół katolicki w Polsce jako część Kościoła powszechnego zobowiązany był do przestrzegania dyrektyw, nakazów i wyroków Stolicy Apostolskiej. Dotyczyło to zwłaszcza potępiania, zakazywania publikacji, rozpowszechniania i lektury pewnych dzieł bądź całej twórczości jakiegoś autora, a nawet określonego typu pism i ich tematyki. Czuwanie nad przestrzeganiem nakazów, zakazów i wytycznych płynących z Rzymu, praktyczne ich wykonywanie, kontrolę i karanie, sprawować miały władze kościelne, w tym lokalne, biskupi i wyznaczane przez nich osoby.

Cenzurę prewencyjną i represyjną druków nakazywała wyraźnie ogłoszona w 1487 r. bulla papieża Innocentego VIII Inter multiplices nostrae sollicitudinis curas $^{1}$.

Podczas Soboru Laterańskiego V, obradującego w latach 1512-1517, na sesji dziesiątej w dniu 4 V 1515 r. przy omawianiu sprawy druku książek stwierdzono, że są wśród nich ,zawierające błędy w wierze i zgubne przekonania, także przeciwne wierze chrześcijańskiej i wymierzone w dobre imię osób, nawet wyróżniających się godnością”. Dbając, ,,aby to, co wynaleziono na chwałę Bożą i dla pomnożenia wiary oraz krzewienia zalet, nie obróciło się w swe przeciwieństwo i nie przyniosło zguby zbawieniu wiernych” podjęto „odpowiedni środek zaradczy, z aprobatą świętego soboru". Papież Leon X postanowił i nakazał, żeby:

na przyszłość, po wieczne czasy, nikt nie podejmował się drukowania lub zlecania do druku żadnej książki czy jakiegokolwiek innego pisma, [...] je-

I Zob. J. Fijałek, Poczatki cenzury prewencyjnej w kościele rzymskokatolickim i w Polsce, [w:] Studia staropolskie. Księga ku czci Aleksandra Brücknera, Kraków 1928, s. 130-134; J. Keller, Zakaz i cenzura ksiażek w kościele, „Studia z Dziejów Kościoła Katolickiego” 1960, nr 2, s. 135-154. 
śli wcześniej nie zostaną one dokładnie zbadane w Rzymie przez naszego wikariusza, teologa papieskiego. W innych zaś miastach i diecezjach przez biskupa lub kogoś innego wyznaczonego przez biskupa [...].

Ten, który nie będzie przestrzegał powyższych zasad:

poza utratą wydrukowanych ksiąg, ich publicznym spaleniem oraz wypłaceniem stu dukatów na budowę bazyliki księcia Apostołów w Rzymie, bez nadziei zwolnienia, z zawieszeniem praktyki drukarskiej na najbliższy rok, będzie obciążony wyrokiem ekskomuniki².

Do tych postanowień o karze anatemy i grzywny z ostatniego Soboru Laterańskiego nawiązano podczas Soboru Trydenckiego na sesji czwartej fazy pierwszej za papieża Pawła III w dniu 8 IV 1546 r., gdy omawiane były sprawy kanonu ksiąg Pisma Świętego, ich druku i przyjęcia wydania Biblii zwanej Wulgata. Doprecyzowano jednak i poszerzono zakres sprawowania i egzekwowania kontroli. Określono

zasady obowiązujące drukarzy, którzy obecnie działają dowolnie, to znaczy uważają, że wszystko im wolno i bez pozwolenia przełożonych kościelnych [w tekście oryginalnym: „sine licentia superiorum”] drukują księgi Pisma Świętego oraz uwagi i wyjaśnienia niezależnie od ich autorstwa, czasem ukrywając, czasem podając fikcyjną nazwę drukarni, a nawet - co jeszcze poważniejsze - pomijając imię autora [,sine nomine auctoris”].

Zabroniono drukowania, zlecania druku wydawnictw o tematyce religijnej bez podania imienia autora, ich sprzedaży i przechowywania bez zbadania i zatwierdzenia biskupa

pod karą anatemy oraz grzywny nałożonej kanonem ostatniego Soboru Laterańskiego. Gdyby zaś ktoś był zakonnikiem, wtedy oprócz tego [to jest przez biskupa ordynariusza] sprawdzenia i zatwierdzenia powinien również otrzymać takie pozwolenie od swych przełożonych zakonnych, którzy sprawdzą publikację wedle zasad u nich obowiązujących.

Aprobacja, ,zatwierdzenie [...] winno się znajdować na stronie tytułowej książki [«in fronte libri»] pisanej ręcznie lub wydrukowanej"3.

W efekcie pojawiały się w książkach aprobaty, a na kartach tytułowych, niekiedy w kolofonach bądź w innych miejscach formuły: Cum licentia Su-

2 Dokumenty soborów powszechnych. Tekst taciński i polski, t. 4: (1511-1870). Lateran V, Trydent, Watykan I, przekł. i oprac. A. Baron, H. Pietras, Kraków 2007, s. 127-129.

3 Wszystkie cytaty z tej sesji zob. tamże, s. 214 (tekst łaciński) i 215 (tłumaczenie polskie). 
periorum, Facultate Superiorum, Superiorum Permissu czy „Z dozwoleniem” (czy też rzadziej „Z pozwoleniem Starszych”, czasami „Z pozwoleniem Przełożonych") itp. Zauważamy je w drukach tłoczonych w Polsce od lat siedemdziesiątych XVI w., zwłaszcza na książkach, których autorami lub thumaczami bądź kompilatorami byli jezuici, a także (rzadziej) inni zakonnicy polscy bądź w Polsce działający.

Później takie formuły umieszczano też w książkach różnych autorów, duchownych i świeckich, a podobne - także na różnowierczych publikacjach poddawanych cenzurze zborowej, „korrekturze” i aprobowaniu. Już na kalwińskim synodzie generalnym w Książu w 1560 r. przestrzegano, by „nikt żadnych ksiąg nie wydawał bez wiadomości starszych”, a w Krakowie w 1575 r. nakazano: „żaden z ministrów nie ma wolności wypuszczać in publicum książek pisanych albo drukowanych nowo pisanych, aż z dozwolenia synodowego"4. I tak "Za radą i dozwoleniem braciej Districtu Lubelskiego" ukazał się w 1599 r. Porządek Nabożeństwa Kościoła powszechnego Apostolskiego... (czyli Agenda dla Kościołów kalwińskich), spisany ,przez Xiędza Krzysztofa Kraińskiego, Superintendenta kościołów reformowanych w małey Polszcze", z fałszywym miejscem druku: „w Toruniu”. Rzeczywiście wytłoczył tę książkę Aleksy Rodecki, starano się jednak ukryć fakt skorzystania z drukarni antytrynitarskiej. W drugim wydaniu tej Agendy w 1614 r., wytłoczonej już przez Sebastiana Sternackiego w Rakowie, nie podano w ogóle miejsca druku, uwidoczniono jednak na karcie tytułowej, że ukazała się ona ,za radą i dozwoleniem Synodu Prowincialnego Ożarowskiego, Włodzisławskiego y Lancutskiego"5. Ponadto w drukarni rakowskiej przy innej książce kalwińskiego kaznodziei jakby zrealizowano, choć częściowo, następny punkt zaleceń trydenckich z 8 IV 1546 r., nakazujących umieszczać na stronie tytułowej informację o zbadaniu i zaaprobowaniu danego dzieła, zamieszczając w trzeciej już edycji K. Kraińskiego Katechizmu z naukami, pieśniami y modlitwami..., wydrukowanego pierwotnie przez S. Sternackiego w 1609 r., słowa: ,wydany z poprawą [...]. Za rewidowaniem Seniorow y consensem Synodow trzech Prowincialnych" ". Natomiast na karcie tytułowej małej książeczki pt. Niektóre psalmy Dawidowe..., składającej się z zaledwie dwóch arkuszy i zawierającej wyjątki tylko z kilku psalmów przełożonych przez kalwinistę Salomona Rysińskiego, znalazły się słowa już nie „o dozwoleniu”

$4 \quad$ Akta synodów różnowierczych $w$ Polsce $=$ Acta synodalia ecclesiarum Poloniae reformatarum, oprac. M. Sipayłło, t. 2: 1560-1570, Warszawa 1972, s. 61; t. 3: Małopolska 1571-1632= Polonia Minor 1571-1632, Warszawa 1983, s. 9.

5 Cyt. za: A. Kawecka-Gryczowa, Ariańskie oficyny wydawnicze Rodeckiego i Sternackiego. Dzieje i bibliografia, Wrocław 1974, s. 160 (nr 34), s. 231 (nr 147).

6 Cyt. za: tamże, s. 229 (nr 145). 
starszych, ale wręcz o wypełnieniu ich polecenia, gdyż miały one zostać przetłumaczone: „Za zleceniem starszych"7.

Inny krótki ustęp postanowień z czwartej sesji trydenckiej o zasadach, które obowiązywały drukujących, rozpowszechniających i sprzedających książki, nakazywał ponadto: ,zatwierdzenie zaś tego rodzaju książek będzie udzielane na piśmie i w pełnym brzmieniu winno się znajdować na stronie tytułowej ${ }^{8}$ książki pisanej ręcznie lub wydrukowanej" ${ }^{\prime}$. Z czasem w książkach pojawiły się - w różnych miejscach: na odwrocie karty tytułowej, po dedykacji czy przedmowie, na końcu tekstu bądź w kolofonie - opinie cenzorów aprobujące tekst, wskazujące, że nie zawiera on nic przeciwnego wierze katolickiej, niekiedy dodawano, że także dobrym obyczajom i że książka jest pożyteczna, może być zatem drukowana. Nakazy podawania prawdziwej nazwy drukarni, nieukrywania jej bądź niepodszywania się pod fikcyjną, piętnujące pomijanie imienia (naturalnie chodzi o nazwisko) autora oraz przypominające o konieczności umieszczania zezwolenia, zatwierdzenia w samej książce były właściwie nagminnie łamane zarówno przez identyfikujących się z łacińskim Kościołem rzymskokatolickim, jak i przez środowiska różnowiercze. Tak samo rzecz miała się z dalszymi nakazami i zakazami dotyczącymi książek wydawanymi przez Stolicę Apostolską, w tym $\mathrm{z}$ dość szczegółowymi regułami poprzedzającymi w Indeksie ksiag zakazanych ich wykaz. W Polsce łatwiej i szerzej dostępne były Reguły z Indeksu ogłoszonego przez Klemensa VIII w 1596 r. dzięki temu, że zbiór ten został w początkach XVII w. trzy razy opublikowany z dodatkami zawierającymi spisy zakazanych, potępionych autorów i książek polskich: w 1603 r. (dzięki bpowi krakowskiemu Bernardowi Maciejowskiemu w Krakowie), 1604 r. (bp chełmski Jerzy Zamoyski w Zamościu), 1617 r. (bp Marcin Szyszkowski w Krakowie). Zarówno w tych przedrukach polskich, jak i w będącym ich podstawą Indeksie... z 1596 r. Regułom towarzyszyły trzy dość rozbudowane rozdziały Instrukcji, składające się z kilku paragrafów. Pierwszy rozdział dotyczył zakazywania książek (De prohibitione librorum), drugi - ich poprawy, korekty (De correctione librorum), trzeci, najobszerniejszy - druku książek (De impressione librorum). Natomiast zasady sformułowane wcześniej, podczas sesji czwartej fazy pierwszej Soboru Trydenckiego, dostępne były w Polsce w różnych edycjach zagranicznych: czy to poświęconych poszczególnym sesjom pierwszej, drugiej i trzeciej fazy lub dekretom na nich

$7 \quad$ Niektóre psalmy Dawidowe częścia poprawione, częścia znowu przełożone na stare noty od Salomona Rysińskiego. Za zleceniem starszych, W Lubczu nad Niemnem: w drukarniey Piotra Blasta, 1614. Dziełko to S. Rysiński przypisał wierszem Krzysztofowi Radziwiłłowi.

8 W tekście lacińskim: „Ipsa vero huiusmodi librorum probatio in scriptis detur atque ideo in fronte libri vel scripti vel impressi, authentice appareat" - cyt. za: Dokumenty soborów..., t. 4, s. 214.

9 Cyt. za: jak wyżej. 
przyjętych, czy to zawierających akta i kanony całego koncylium. Dziś tomy ze wspomnianymi wytycznymi znajdziemy głównie w bibliotekach kościelnych (np. w bibliotece franciszkanów w Krakowie zachowały się akta sesji piątej wydrukowane w Antwerpii w 1547 r.).

Sporo jest tego rodzaju wydawnictw w Bibliotece Uniwersytetu Warszawskiego [dalej: BUW], zarówno dekretów z poszczególnych sesji (w tym takich, które publikował w Brescii Giovanni Battista Bozolla), jak i dekretów z przebiegu całego soboru, z proweniencjami polskimi z XVI w. (głównie duchownych i domów zakonnych, ale też osób świeckich). W BUW są zarówno trydenckie Canones et decreta ... Concilii Tridentini..., (Romae: Apud Paulum Manutium..., 1564), jak i wytyczne w wydaniu wspomnianego G.B. Bozolli: Universum sacrosanctum Concilium Tridentinum, oecumenicum ac generale, legitime, tam inductum tum congregatum sub ... pont. max. Paulo III ... Julio III ... et Pio Quatro ... nunc recens quam emendatissime in lucem prodit (Coloniae: apud Maternum Cholinum; typis Godefridi Cervicorni, 1564) ${ }^{10}$. Niektóre wydania zawierają też Indeksy ksiąg zakazanych, zarówno z 1564, jak i 1596 r.

Druki (i relacje rękopiśmienne) przedstawiające obrady Soboru Trydenckiego docierały do Polski wcześnie, choć naturalnie dostęp do nich był ograniczony. Niektóre napływające wiadomości wywoływały żywy odzew. Jak informował kardynała Karola Boromeusza z Warszawy nuncjusz Jan Franciszek Commendone, nadesłane wyroki (czyli kanony i dekrety) z przedostatniego posiedzenia trzeciej fazy soboru z 11 X 1563 r., na którym omawiano sprawy dotyczące małżeństwa i wewnętrznej reformy Kościoła, w tym sposobu ustanawiania biskupów i kardynałów, synodów prowincjonalnych, wizytacji, beneficja, ,po całym dworze nagle się rozeszły" i były żywo omawiane ${ }^{11}$.

Formalnie król przyjął księgę ustaw soboru z rąk nuncjusza 7 VIII 1564 r. podczas sejmu w Parczewie w obecności członków senatu. Nie oznaczało to jednak rozpoczęcia wdrażania w Polsce zapadłych w Trydencie postanowień, nawet nie omawiano ich wtedy, choć prymas Jakub Uchański chciał, by zapoznano się z treścią księgi.

Jeszcze większe opóźnienia były w Kościele polskim, nawet z formalnym przyjęciem reform trydenckich. Akceptacji Trydentu miał dokonać sy-

10 Druki związane z Soborem Trydenckim (niektóre edycje w kilku egzemplarzach) znajdują się w zestawieniu: Katalog druków XVI wieku w zbiorach Biblioteki Uniwersyteckiej w Warszawie, t. 3: C-E, red. H. Mieczkowska, materiał proweniencyjny oprac. pod kier. M. Cubrzyńskiej-Leonarczyk, Warszawa 2007, s. 324-339 (opisy nr 2560-2609).

11 Listy nuncjusza w przekładzie Józefa Krzeczkowskiego zostały opublikowane w $1851 \mathrm{r}$. w Wilnie - zob. Pamiętniki o dawnéj Polsce z czasów Zygmunta Augusta, obejmujace listy Jana Franciszka Commendoni do Karola Boromeusza z Biblioteki Berberiańskiej, t. 1-2, zebrał J. Albertrandi. J.F. Commendone wyruszył z Włoch jeszcze przed zakończeniem soboru, do Polski przybył w listopadzie $1563 \mathrm{r}$. 
nod prymacjalny obu prowincji, gnieźnieńskiej i lwowskiej, ale jego termin - pierwotnie wyznaczony na 17 XII 1564 r. - był przesuwany, ostatecznie zjazd odbył się dopiero 19 V 1577 r. Stolica Apostolska i kolejni nuncjusze, J.F. Commendone, Juliusz Ruggieri i Wincenty dal Portico, obawiali się, aby nie przekształcił się on w sobór narodowy, mieli bowiem wątpliwości co do postawy prymasa J. Uchańskiego.

Przed synodem plenarnym piotrkowskim z 1577 r. odbyły się wprawdzie synody w trzech diecezjach: poznańskiej w końcu października 1564 r. za bpa Adama Konarskiego, warmińskiej, której biskupem był kardynał Stanisław Hozjusz w listopadzie 1565 r. i następny w 1575 r. w nieobecności Hozjusza pod przewodnictwem jego koadiutora Marcina Kromera oraz w diecezji kujawsko-pomorskiej (włocławskiej) Stanisława Karnkowskiego w 1568 r. Jeszcze pod koniec 1564 r. miał natomiast miejsce synod prowincji lwowskiej arcybiskupa Pawła Tarły. Był na nim nuncjusz J.F. Commendone. Nakłonił on zebranych do przyjęcia postanowien trydenckich, choć początkowo chciano zostawić to przyszłemu synodowi plenarnemu, pod przewodem prymasa. Także synod poznański bpa A. Konarskiego pełniejszą akceptację uchwał trydenckich przesunął na przyszły synod prymacjalny. Zresztą na wszystkich wspomnianych synodach obradowano tylko nad niektórymi sprawami omawianymi w Trydencie i w takim też zakresie podejmowano postanowienia. Stosunkowo niewiele zajmowano się książkami - podnoszono kwestię kontroli nad nimi i zakazywano, jak wcześniej, druków uznanych za heretyckie lub podejrzane, a zwłaszcza używania ich w szkołach, zalecano też książki potrzebne w duszpasterstwie, postylle i katechizmy. Na drugim potrydenckim synodzie warmińskim w 1575 r. polecono, by kapłan na spowiedzi pytał o niedozwolone lektury. Zajęto się także sprawą książek ,podejrzanych” - według zapisów trydenckich były nimi wszystkie publikacje, w których nie podano nazwiska autora lub drukarza. Nakazano sprawdzanie książek oferowanych do kupna, duchowni mieli pouczyć władze miejskie o konieczności ich kontroli. W opublikowanych w 1612 r. aktach synodu z 1575 r. jest ponadto Bulla in coena Domini ${ }^{12}$. W pierwszym jej punkcie drukujących, czytających, przechowujących, broniących książki heretyckie uznano za równie winnych, co heretycy, schizmatycy i sekciarze.

Sprawy dotyczące książek omawiane i rozstrzygane na synodach traktowano przede wszystkim jako wchodzące w zakres działalności duchownych, ich czuwania nad prawowiernością wiernych, kontrolowania, zapobiegania nieprawomyślności, herezji. Nie widać zainteresowania częścią, omówionych wyżej, postanowień przyjętych na sesji czwartej fazy pierwszej soboru (za Pawła III) z 8 kwietnia 1546 r. dotyczących druku ksiąg.

12 Zob. Constitutiones Synodales Dioecesis Varmiensis..., Brvnsbergae: apud Georgium Schönfels, 1612. Jest to zbiór dokumentów kilku synodów warmińskich. 
Pomijane na synodach kwestie, uwzględnił - choć w pewnym uproszczeniu i z opuszczeniami - Marcin Siennik w małej (56 kart) książeczce pt. Koncilium Trydentskiego, nowoskończonego Wyroki y Vstawy ... wydane przez Jana Baptystę Bozolę tacińskim ięzykiem: a Marcin Siennik, samy ustawy tylko, na polskie przetożyt, dla ludu pospolitego co nakrocey być mogło, wydrukowanej po 28 XII 1564 r. bez nazwiska drukarza, tj. w 1565 r. (,za Nowe Lato” czyli noworoczny podarunek) przez Łazarza Andrysowicza w Krakowie ${ }^{13}$. M. Siennik, człowiek rzeczywiście związany z książką, choć podejmujący się różnych zajęć, przetłumaczył z łaciny tylko „same wprawy, co je łacinnicy kanony zwą”. Niektóre skracał, a nawet opuszczał, zwłaszcza te, które wprost dotyczyły kapłanów i zakonników, bo ci mogą przeczytać je po łacinie. Tak też postąpił, dając na $\mathrm{k}$. $\mathrm{B}_{2} \mathrm{v}-\mathrm{B}_{3}$ Wprawe IV z sesji czwartej:

Aby theż prasownicy albo drukarze $\mathrm{w}$ tym porządek mieli: nie mają Pisma swiętego ani Wykładów jego wytłaczać bez wiedzenia i dozwolenia Przełożonych Kościelnych. Ani tych przedawać, które kryomie a bez imion wydawcow robione beły. Abowiem występcy mają być od biskupów karani ${ }^{14}$.

Niektórzy kapłani i zakonnicy oraz ich przełożeni z pewnością przeczytali po łacinie cały ten ustęp o książkach, ich druku, ,sprawdzaniu” i konieczności uzyskania przez zakonników ,pozwolenia od przełożonych”. Pierwsza książka autorstwa Piotra Skargi, jezuity (od 1569 r. - przedtem kanonika i kaznodziei katedralnego lwowskiego), Pro Sacratissima Eucharistia contra haeresim Zuinglianam ... libri tres, będąca zarazem debiutem nowo uruchomionej w Wilnie drukarni marszałka Mikołaja Krzysztofa Radziwiłła (wkrótce zresztą przekazanej jezuitom) ukazała się w 1576 r. właśnie ze słowami: Cum facultate Superiorum, ,z formułką chyba tu właśnie użytą po raz pierwszy” ${ }^{15}$ w państwie polsko-litewskim, zamieszczoną pod adresem wydawniczym. Przy druku tego polemicznego dzieła, będącego odpowiedzią na wymierzoną imiennie w P. Skargę publikację Andrzeja Wolana Vera et orthodoxa veteris ecclesiae sententia de sacramento corporis et sanguinis Christi ad Petrum Skarga per Andream Volanum, wytłoczoną w 1574 r. w różnowierczej typografii w Łosku, wykonano więc zalecenia sformułowane w postanowieniach czwartej sesji Soboru Trydenckiego: nie ukryto autora ani nazwy drukarni oraz poinformowano, iż druk wydano z „Zezwoleniem Przełożonych”. Formułę tę, czy to w ję-

13 M. Siennik, Koncilium Trydentskiego, nowoskończonego Wyroki y Vstawy..., Kraków: [drukarnia Łazarza Andrysowicza], 1565. Unikat Biblioteki Narodowej, sygn. XVI.0. 6214.

14 Cyt. za: jak wyżej.

15 Zob. A. Kawecka-Gryczowa, Miejsce ksiązki w kulturze polskiej XVI wieku, [w:] Polska w epoce Odrodzenia: państwo, spoleczeństwo, kultura, pod red. A. Wyczańskiego, Warszawa 1986, s. 428. 
zyku polskim, czy łacińskim: Cum licentia Superiorum, Superiorum permissu lub jak u P. Skargi - Cum facultate Superiorum, możemy przeczytać na wielu drukach z XVI, XVII i XVIII w. (a w XX w. np. „Za zezwoleniem Władzy Duchownej”, choć częściej - Imprimatur). Sformułowaniom tym z czasem towarzyszyć zaczęły pełniejsze zapisy aprobaty i dokonanej cenzury, niejednokrotnie wielokrotnej - w wielkim objętością tomie pierwszym z planowanych dziesięciu dzieła dominikanina Seweryna Lubomlczyka Monotessaron Evangelicum... (1606 r., krakowska Architypographia Jana Januszowskiego) jest ich siedem z lat 1603-1605 ${ }^{16}$, a określone są jako: polecenia (mandatum), świadectwa (testimonium) i licencje.

Wcześniejsze od znanych przypadków umieszczania na kartach tytułowych (rzadziej - na końcu książki) zezwoleń w drukach wytłoczonych w Polsce jest pojawianie się słów tego typu w pismach polskich autorów, które zostały wydane w oficynach zagranicznych. I tak np. w 1574 r. w Rzymie „Apud Haeredes Antonij Bladij Impressores Camerales” ze słowami o zezwoleniu przełożonych ukazał się dedykowany kardynałowi Aleksandrowi Farnese, protektorowi Polski, przygotowany przez Stanisława Reszkę niewielki zbiorek pism związanych z elekcją i przybyciem do Polski Henryka Walezego pt. De rebus in electione, profectione coronatione Henrici Regis Poloniae in Gallia et in Polonia gestis. Cum licentia Superiorum, a także w tej samej oficynie w 1580 r. tegoż S. Reszki Epistola Stanislai Rescii de Transitu et Dormitione ... Stanislai Hosii ... Cum licentia Superiorum (nb. list ma datę: w Rzymie XVII Cal. Sept. 1579).

Interesujące, że formuła ta pojawiła się $\mathrm{w}$ drugim wydaniu przetłumaczonego przez Stanisława Sokołowskiego i wydanego najpierw w Krakowie w 1582 r., a powtórnie - w tymże samym roku w Dylindze dzieła Censvra Orientalis Ecclesiae. De praecipvis nostri saecvli haereticorvm dogmatibvs; Hieremiae Constantinopolitano Patriarchae, iudicii ... Ab eodem Patriarcha Constantinopolitano, ad Germanos Graece conscripta: A Stanislao ... Socolovio ..., ex graeco in latinum conuersa ... Inna formuła: Venia a Superioribus concessa jest na dwóch drukach związanych z elekcją Henryka Walezego opublikowanych w Bolonii. Autorem ich był także Polak - Jan Andrzej Krasiński, studiujący wówczas we Włoszech. Niewielki druk pt. Oratio Joannis Crassinii Equitis Poloni, de electione Henrici Valesii Polonorum regis, ad Senatum et Equites Polonos ukazał się w 1573 r. W 1574 r. światło dzienne ujrzał natomiast znacznie obszerniejszy opis geograficzno-polityczny Polski: ... Polonia. Ad ... Henricum primu[m] Valesium... napisany za poradą Carolusa Sigoniusa, którego J.A. Krasiński był uczniem. Także w drukach

16 Są to trzy wydane w Rzymie i cztery - w Krakowie: polecenia (mandatum), świadectwa (testimonia) i licencje. Nota bene generał dominikanów zabronił druku dalszych tomów. 
wytłoczonych w Polsce formuła zezwolenia mogła być nieco modyfikowana, a przede wszystkim - pojawiać się na książkach różnego typu. W ostatniej ćwierci XVI w. były one często autorstwa jezuitów. Zdarzało się też, że formułę tę wprowadzano dopiero w kolejnym przedruku. Tak było np. w przypadku Benedykta Herbesta, pisarza pedagogicznego i teologicznego, polemisty i retora, wykładowcy w Akademii Krakowskiej i Kolegium Lubrańskiego, który w 1571 r. został jezuitą. Wśród kilkunastu jego dzieł są dwie książki $\mathrm{z}$ formułą zezwolenia. Arithmetica linearis... dopiero w piątym wydaniu z 1577 r. otrzymała zapis: cum facultate superiorum. Natomiast praca Wiary Kościoła Rzymskiego wywody, y greckiego niewolstwa historya... została wydana u Piotrkowczyka w 1586 r. z trochę zmienioną formułą: „za Starszych swoich pozwoleniem". Podobnie z kilku druków paulina Mikołaja z Wilkowiecka tylko na jednym - wydrukowanej w Krakowie w 1577 r. Historyji o świętey Annie... - możemy przeczytać: ,Z własnym dozwoleniem Przełożonego swojego"; słów tych brak na podobnym druku Historyji o s. Stanisławie... z $1578 \mathrm{r}$.

W tym czasie częściej słowa o dozwoleniu czy pozwoleniu znajdujemy na książkach autorstwa bądź thumaczenia jezuitów, ale też dominikanów i paulinów. Dość często słowom o pozwoleniu „starszych” towarzyszył skrócony zapis o przywileju królewskim, którym legitymizował się drukarz, jednak rzadko łączono to, tak jak na karcie tytułowej przełożonej przez pewnego zakonnika Societatis Jesu (prawdopodobnie Szymona Wysockiego) z języka włoskiego opowieści o życiu i śmierci księżnej parmeńskiej autorstwa Sebastiana Moralesa (drukarnia Lazarzowa, 1581 r.): Cum Gratia et Privilegio S.R.M. et facultate Superiorum. Słowa o zezwoleniu - Cum facultate Superiorum - są też na druku jakby „służbowym” jezuitów: Regvlae Societatis Jesv... (Vilnae: In Collegio eiusdem Societatis, 1582). Nota bene formuła ta stosunkowo często pojawiała się na drukach poznańskich i wileńskich (zwłaszcza jeśli pamiętamy o tym, że ukazywało się ich mniej niż wydawnictw krakowskich). Choć kanonik poznański Piotr Lilia, doktor teologii, opublikował kilka książek w języku łacińskim w Poznaniu, Krakowie i Wilnie, to Cum licentia superiorum widnieje tylko na jednym druku, wydanym w Wilnie w 1584 r. (Responsio Petri Liliae ... ad cuiusdam Nicolai Regii Germani epistolam...).

„Z dozwoleniem przełożonych” ukazał się w 1583 r. w Drukarni Łazarzowej Rozaniec pospolicie Rozany Wianek ... Z ksiag ... Lvdwika z Granaty ... zakonnika porzadku kaznodzieyskiego ... z włoskiego na polskie przez Antonina z Przemyśla tegóż zakonu lektora wyłożony... Ale inne dzieło Ludwika z Granady w przekładzie ,jednego kapłana Societatis Jesu” (Stanisława Warszewickiego) podobną formułę ma dopiero w czwartej edycji u Piotrkowczyka w Krakowie w 1598 r. (po poznańskich wydaniach z 1577 i 1585 r. oraz wileńskim z 1594 r.). 
Oprócz dozwoleń „przełożonych” bądź „starszych” możemy znaleźć na kartach tytułowych słowa Iussu et auctoritate, Iussu et mandato, Cum licentia et authoritate prymasa, biskupów, nuncjuszy: S. Karnkowskiego, J. Uchańskiego, Łukasza Kościeleckiego, Jerzego Radziwiłła, Alberta Bolognettiego, Hannibala de Capua. Natomiast w innych miejscach: na odwrocie karty tytułowej, po przedmowie, na końcu tekstu zamieszczane były (w ostatniej ćwierci XVI w. jeszcze dość rzadko) teksty cenzur, aprobat lub choćby zezwolenia na druk. Sporą aktywność w tym zakresie wykazał w Poznaniu ks. Jan Młodujewski, „librorum censor ordinarius”, doktor świętej teologii, kanonik, który podpisał cenzury w sześciu drukach poznańskich z lat 1585-1594. Nota bene zabroniono Janowi Wolrabowi druku dzieł ,,rozbierających błędy innowiercze" bez uprzedniego pozwolenia cenzury biskupiej ${ }^{17}$.

W pierwszej opublikowanej książce P. Skargi brak takich świadectw wielokrotnych i dość długo trwających ocen przez różne osoby i instancje, tak jak to było w przypadku S. Lubomlczyka. Jednak zrealizowanie jej edycji nie było ani szybkie, ani łatwe. A przecież książkę A. Wolana o sakramencie ciała i krwi Chrystusa, wytłoczoną w Łosku, atakującą P. Skargę, potępił jako heretycką i zakazał jej czytania, sprzedawania i posiadania biskup wileński Walery Protasewicz (Szuszkowski) już 1 VIII 1574 r. Sam P. Skarga w liście z 30 IX 1574 r. do wiceprowincjała Franciszka Suniera ${ }^{18}$ przy okazji informowania o ukazaniu się nowego polskiego thumaczenia - autorstwa Szymona Budnego - Nowego Testamentu wspomniał, że wyszło ono w tej samej drukarni łoskiej, co dzieło A. Wolana przeciwko jezuicie. Obszerna (468 s. in $8^{\circ}$ ) odpowiedź P. Skargi ukazała się dopiero w 1576 r. Dedykacja była datowana w Wilnie 12 V 1576 r., a na początku lipca autor przesłał generałowi zakonu jezuitów Everardowi Mercurianowi egzemplarz publikacji. Przedtem jednak sprawa przygotowania i druku polemiki Skargi, wiążąca się z przekonywaniem o tym, że odpowiedź na książkę A. Wolana powinna być opracowana i wydana w Polsce (kard. Hozjusz proponował zamiast tego opublikowanie dyskwalifikującej dzieło A. Wolana książki pióra teologa hiszpańskiego Franciszka Turriana ${ }^{19}$, która ukazała się w 1575 r. we Florencji, a w 1576 w Rzymie), wracała w korespondencji P. Skargi (i innych osób uwzględnionych w zbiorze J. Sygańskiego) kilkakrotnie - listy nr 35, 40, 41, 43 z 1575 i 1576 r. W liście nr 39 do generała Mercuriana z 4 V 1575 r. jezuita pisał, że taka odpowiedź winna być w imieniu Kolegium Wileńskiego, nawet

17 Zob. M. Wojciechowska, Z dziejów książki w Poznaniu w XVI wieku, Poznań 1927, s. 57.

18 Wszystkie cytowane tu listy P. Skargi, a także innych osób jego dotyczące zamieszczone są (w układzie chronologicznym) w wydanym przez ks. Jana Sygańskiego w Krakowie w 1912 r., nakładem Wydawnictw Towarzystwa Jezusowego, zbiorze pt. Listy ks. Piotra Skargi T.J. z lat 1566-1610. W tekście podaję datę listu i nr w tym zbiorze oraz ewentualnie stronę.

19 Edycja florencka z 1575 r.: Francisci Turriani Societ. Iesu Contra Andream Volanum Polonum Caluini discipulum de Sanctissima Eucharistia tractatus ... Eiusdem contra eundem Volanum, et omnes Metonymicos alter tractatus de eadem Sanctissima Eucharistia... 
z pominięciem rzeczywistego autorstwa Skargi, pod innym nazwiskiem (s. 76). Znamienne jest, że gdy wreszcie odpowiedź P. Skargi zbijająca wywody A. Wolana ukazała się (z nazwiskiem zakonnika), to już w pierwszej jej części, na s. 9, zamieszczono na marginesie uwagę: „Judicium Episcopi Vilnen. de libro Volani”, a więc wspomniane już potępienie ich przez W. Protasewicza z 1 VIII 1574 r.

W liście nr 58 z 16 XII 1579 r. do nuncjusza Jana Andrzeja Caligariego Skarga pisał, że gdyby miał czas i jego ,przełożeni p o z w o 1 i 1 i” (s. 111: „si tantum haberem otii et mei superiores permitterent”), to z siedmiu słów, wokół których skomponował kazanie pogrzebowe Katarzyny Radziwiłłowej, żony Krzysztofa Radziwiłła „Rudego”, przygotowałby książkę w języku polskim. Jednak w tym właśnie dziele pt. Siedm filarów... z 1582 r., zbijającym błędy nauki zwingliańskiej i kalwińskiej A. Wolana i jakiegoś „,ciemnego ministra”, autora nieznanej nam Pedagoiey, oraz wcześniejszym $O$ jedności Kościoła Bożego pod jednym Pasterzem... z 1577 r. czy w wydanym również w 1582 r. łacińskim Artes duodecim... brak zapisu takiego zezwolenia choćby w tej, wiele razy przytaczanej postaci: Cum facultate Superiorum lub jej odpowiednika w języku polskim. Brak jej także w wielu późniejszych publikacjach P. Skargi z lat 1584-1610, kilka w latach 1584-1601 zostało zresztą wydanych bez jego nazwiska, choć przecież Trydent piętnował anonimowość i autorów, i drukarzy.

W rezultacie więcej dzieł P. Skargi (20) ukazało się bez formuły, którą zamieszczono na pierwszej jego książce (z 1576 r.): Cum facultate Superiorum, lub jej odpowiedników. „Z dozwoleniem starszych” ukazywały się Żywoty świętych... ${ }^{20}$, Kazania na niedziele i święta, Kazania o siedmiu sakramentach, Żotnierskie nabożeństwo i Kazania przygodne, a Wtore zawstydzenie arianow w 1608 r. u A. Piotrkowczyka - Cum licentia Superiorum. Natomiast Roczne dzieje kościelne ... wybrane z Roczników dziejów kościelnych Cesara Baroniusza, kardynała... zostały przygotowane, wybrane i przetłumaczone przez P. Skargę „Z dozwoleniem tegoż kardynała i Starszych”.

Przy Probie Zakonu Societatis Iesv... z 1607 r. zmodyfikowana formuła: „Z poruczenia starszych”, umieszczona po słowach: „Pisana od X. Piotra Skargi Societatis Jesu", sugeruje, że odnosi się właśnie do czynności podjętej niejako na polecenie „Starszych”.

P. Skarga uważnie i starannie przygotowywał swoje teksty ${ }^{21}$, także do dalszych wydań. Na wznowieniach są informacje o „przejźrzeniu”, „przy-

20 Nie wiemy, czy już w pierwszej edycji z 1579 r., gdyż w zachowanych egzemplarzach brak karty tytułowej części pierwszej, a na niej w dalszych edycjach formuła była drukowana.

${ }_{21}$ W mowie Na pogrzebie ... X. Piotra Skargi ks. Szymon Birkowski tak wspominał o dążeniu zmarłego do uzyskania jak najlepszej wersji tekstu: „i raz, i drugi, czasem do trzeciego razu kazanie jedno [...] pisywał" (k. XX 1 w wydaniu: Kraków: Piotrkowczyk, 1612; ukazało się ono też „Z dozwoleniem Starszych”). 
daniu" czegoś. Zmieniała się zawartość książek, zwłaszcza zbiorów kazań, ale i Żywotów świętych.... W edycji z 1585 r. w dedykacji ich (cz. II) Annie Kormanickiej (po usunięciu poprzedniej z 1579 r. dla Mikołaja Mieleckiego) napisał, że Żywoty... „znowu przeyźrzał, rozszerzył y ostrożniey ... wydał y wydrukować za dozwolenim starszych dopuścił". Jezuita zmieniał też teksty, dodawał bądź usuwał pewne fragmenty bądź nawet jakieś słowo „oczyszczał” lub poprawiał. Według Andrei Ceccherellego Żywoty... poddane były potrójnej cenzurze. Była to „cenzura tłumacza na źródle, cenzura przełożonych Skargi, autocenzura" 22 . Istnienie wariantów tekstowych Żywotów... i innych dzieł P. Skargi dokumentuje i omawia Magdalena Komorowska ${ }^{23}$, ale dostrzegł je już Adam Jocher i inni bibliografowie. Dwa lata przed opublikowaniem Żywotów... przesłał je P. Skarga w 1577 r. do Rzymu S. Hozjuszowi. Na stronie tytułowej Rocznych dziejów kościelnych... Baroniusza w opracowaniu Skargi widnieją, jak to już przytoczyłam, słowa: „Z dozwoleniem tegoż kardynała i Starszych”, na pierwszej edycji z 1603 r. jest też informacja: „Te księgi zamykają w sobie dziesięć tomów”, a w drugiej edycji z 1607 r. mowa w dwunastu tomach oryginału C. Baroniusza. P. Skarga bardzo starał się uzyskiwać zgodę władz zakonnych na swe poczynania pisarskie, a zwłaszcza publikowanie swych dzieł, co widać już z listów przed jego debiutem i ukazaniem się Pro Sacratissima Eucharistia... w 1576 r. Korespondencja jezuity ${ }^{24}$ dostarcza wielu informacji na temat uzyskiwania bądź choćby starań o otrzymanie „dozwolenia”. Wiele wyczytać możemy też z listów Jakuba Wujka ${ }^{25}$, ale historia jego autorskich, a zwłaszcza edytorskich poczynań i ich efektów zasługuje na osobne, obszerniejsze omówienie (przygotowuję je). Wiele dzieł J. Wujka, w tym przekłady książek, ukazało się anonimowo. Choć udokumentowane i znane są przeszkody, na jakie natrafiał on w drodze do drukarń (zwłaszcza jego długotrwałe starania o możliwość tłumaczenia i druku Biblii), w swych listach J. Wujek raczej niewiele pisze o tych problemach oraz o uzyskaniu pozwolenia na opracowanie jakiegoś dzieła i jego wydanie. Wspominał natomiast o „dozwoleniu” czytania „braciom” w języku polskim dzieł jak najbardziej katolickich: Postyllae, De imitatione Christi, De contemptu mundi papieża Innocentego III, Guida di peccatori Ludwika z Granady, Meditationes Granatae, a więc tekstów opracowanych, thumaczonych przez niego samego i innych jezuitów.

22 A. Ceccherelli, Od Suriusa do Skargi. Studium porównawcze o „Żywotach świętych”, Izabelin 2003, s. 158.

23 Zob. M. Komorowska, Prolegomena do edycji dziet Piotra Skargi, Kraków 2012.

24 Listy ks. Piotra Skargi...

25 Zob. Korespondencja księdza Jakuba Wujka z Wagrówca z lat 1569-1596. Podtug autografów, wydał J. Sygański, „Roczniki Towarzystwa Przyjaciół Nauk Poznania”, 1917-1919, t. 44-46, s. 295-359 (i odbitka). Kilka listów z lat 1569, 1570 i 1588 opublikował J. Poplatek w „Polonia Sacra” 1950, z. 1-4. 
Interesujące są także historie autorskie i wydawnicze innych jezuitów, w tym zwłaszcza Adriana Jungi (urodzony na Mazowszu, w Płońsku, w rodzinie szkockiej, do Towarzystwa Jezusowego wstąpił w 1573 r.). Niektóre dzieła tego jezuity ukazywały się „Z dozwoleniem starszych” i pozwoleniem na druk danym przez poznańskiego cenzora diecezjalnego, inne - pod nazwiskiem mecenasa - arcybiskupa S. Karnkowskiego, co potwierdza nekrolog A. Jungi i notatka w katalogu zakonnym z 1602 r. Około 1605 r. zakonnik otrzymał pozwolenie na pisanie i wydawanie nowych dzieł (zmarł w 1607 r.) $)^{26}$.

Mniej niż o jezuickiej drodze do uzyskania „dozwolenia” wiemy na temat analogicznych starań innych zakonników, a także na temat kłopotów i trudności z publikacją prac kapłanów niebędących zakonnikami i świeckich przy istnieniu cenzury uprzedniej, prewencyjnej, ale i represyjnej, kontrolowaniu, sprawdzaniu drukarń i bibliopolów. Jednak uzyskanie „dozwolenie” dużo tu znaczyło i często pojawiało się ono na książkach.

\section{Streszczenie}

W artykule wskazano na pojawienie się w niektórych drukach szesnastowiecznych (i późniejsze długie i powszechniejsze stosowanie) stereotypowej formuły potwierdzającej, że ukazały się one z pozwoleniem odpowiednich władz, określanych, jako „starsi” bądź „przełożeni”. Wiązało się to z cenzurą prewencyjną, a zwłaszcza oddziaływaniem postanowień Soboru Trydenckiego dotyczących książek. 8 IV 1546 r. na sesji czwartej pierwszej fazy Soboru Trydenckiego nawiązując do postanowień wcześniejszego Soboru Laterańskiego (4 V 1515) określono zasady obowiązujące drukarzy. Nakazano umieszczanie autora i nazwy drukarni na karcie tytułowej. Pod karą anatemy i grzywny zabroniono druku i sprzedaży książek bez badania i zatwierdzenia przez biskupa, a w przypadku dzieł autorstwa zakonników, dodatkowo przez ich przełożonych. W drukach świadczących o zbadaniu dzieła i wskazujących, że nie zawierają one nic przeciwnego wierze, czasem także dobrym obyczajem pojawiły się też w Polsce skrócone formuły Cum licentia Superiorum, Facultate Superiorum, Superiorum Permissu czy „Z dozwoleniem” bądź „Pozwoleniem starszych". Proces nawet formalnego przyjęcia ustaw soboru zakończonego w grudniu 1563 r. przebiegał powoli. Księgę ich ustaw przyjął król z rąk nuncjusza 7 VIII 1564 r. W latach 1564-1568 wdrożono postanowienia trydenckie w trzech diecezjach. Formuła Cum Facultate Superiorum pojawiła się w 1576 r. na książce (pierwszej!) autorstwa Piotra Skargi, a zarazem pierwszej z nowo uruchomionej drukarni w Wilnie. Wcześniej podobne słowa znalazły się na zagranicznych edycjach Polaków (np. w 1574 r. Stanisława Reszki).

26 B. Natoński, Junga Adrian, [w:] PSB, t. XI, Wrocław-Warszawa-Kraków 1964-1965, s. 324-326. 
Liczne zastosowanie tej formuły stopniowo wzrastało, zwłaszcza na drukach jezuitów, choć brak jej na wielu ich książkach, w tym na większości dzieł Skargi. Są one natomiast na wielokrotnie wznawianych Żywotach i Kazaniach Piotra Skargi.

Slowa kluczowe: Sobór Trydencki - cenzura prewencyjna - cenzura represyjna - Jakub Wujek - Piotr Skarga.

\section{Summary}

\section{Printed with approbation}

The article indicates phenomenon of existence on some 16th century prints (and later ones, very commonly) stereotypical formula which confirmed, that they were published with approbation of adequate authorities described as „elders" or „superiors”. Discussed phenomenon was connected with preventive censorship, specifically with influence of decisions of Council of Trent on books. $8^{\text {th }}$ of April 1546, on the fourth session of the first phase of Council of Trent referring to decisions of the earlier Council of Lateran ( $4^{\text {th }}$ of May 1515) there were defined the rules printers should had obey. It was ordered that author's name and name of the printing shop should be explicitly shown on the title page. Printing and selling books without examination by and approval of the bishop was forbidden under the punishment of anathema and fine, in a case of books written by monks additional approval by their superiors was obligatory. In Poland in the prints confirming examining the book and indicating they did not contain any content against the faith (sometimes also against good habits) there appeared shortened formula Cum licentia Superiorum, Facultate Superiorum, Superiorum Permissu (with approbation or acceptance of the Elders). The process of even formal introduction of the Council (ended in December 1563) Acts' went on very slowly. The King received the Book of Council Acts from nuncio on $7^{\text {th }}$ of August 1564. In the period 1564-1568 the Trident Council's decisions were introduced in three dioceses. The formula Cum Facultate Superiorum appeared in the year 1576 r. on the (first!) book by Piotr Skarga, which was also the first book produced in the newly established printing shop in Vilnius. These words could be also found in the foreign editions of books written by Poles (e,g. Stanisław Reszka, 1574). Usage of this formula gradually grew, specifically within the Jesuits prints, however it is still absent from many of their books, including majority Skarga's works. This formula might be found in frequently re-printed Skarga's „Sermons” and „Lives of the Saints”.

Key words: Council of Trent - preventive censorship - repressive censorship - Jakub Wujek - Piotr Skarga. 